педагогам для выработки правил и норм использования электронных гаджетов детьми 6-7-летнего возраста.

\title{
Литература
}

1. Божович Л.И. Проблемы формирования личности /под ред. Д.И.Фельдштейна. М.: Институт практической психологии. 1995.

2. Выготский Л. С. О двух направлениях в понимании природы эмоций в зарубежной психологии вначале ХХ в. // Вопросы психологии. 1968. № 2.

3. Некрасов С.Д. Математические методы в психологии (MS Excel). Краснодар: Кубанский гос. ун-т, 2014. URL: http://docspace.kubsu.ru/docspace/handle/1/295.

4. Некрасов С.Д. Как составить психологический портрет человека. Краснодар: Кубанский гос. ун-т, 2016.

\section{ВЛИЯНИЕ ДЕТСКО-РОДИТЕЛЬСКИХ ОТНОШЕНИЙ НА МЕЖЛИЧНОСТНОЕ ВЗАИМОДЕЙСТВИЕ СТАРШИХ ДОШКОЛЬНИКОВ СО СВЕРСТНИКАМИ}

Бочкарева C.H.

Развитие ребенка в каждой семье зависит от характера сложившейся в ней отношений, от стиля и типа воспитания и личности самих родителей. Можно с уверенностью сказать, что эти отношения определяют будущее человека: его отношения с окружающими, особенности поведения и характера. В современное время родители стали чаще обращаться к психологу за помощью в плане воспитания детей. Создаются центры, в которых родители учатся взаимодействовать со своими детьми. Поэтому тема зарождения и становления межличностных отношений между родителями и между сверстниками чрезвычайно актуальна, так как множество негативных и деструктивных явлений среди молодежи, наблюдаемых в последнее время (жестокость, отчужденность, агрессия) имеют свои истоки в раннем и дошкольном детстве, основанные на детско-родительских отношениях и отношениях со сверстниками.

Так в психологическом словаре термин «общение» рассматривается как процесс установления и развития контактов между людьми, порождаемый их потребностями в совместной деятельности. Общение объективно порождается совместной жизнедеятельностью людей в системах их внешних отношений с социальной средой и внутри групповых межличностных отношении.

По выражению В.А. Петровского, “в процессе осуществления деятельности человек объективно вступает в определенную систему взаимосвязей с другими людьми". Таким образом, содержанием любого взаимодействия является связь, обмен (действиями, предметами, информацией и т.д.) и взаимное влияние.

Семейное общение является существенной частью функционирования общества как такового. Однажды у Конфуция поинтересовались, почему мудрец не участвует в государственных делах и на это китайский философ ответил следующим образом: "В повседневности проявляю разумное 
отношение к близким, почитаю старших и добр с младшими, проявляю заботу о других - разве это не есть управление государством и участие в государственных делах".

Именно в семье дети приобретают первые навыки взаимодействия, осваивают первые социальные роли, нормы и ценности. Тип поведения родителей оказывает воздействие на формирование личности ребенка. Именно семья определенным образом влияет на процесс и результаты формирования личности. В семье вырабатываются многие качества личности, которые нигде, кроме родительского дома не могут быть воспитаны. Из этого следует, что родители должны на научно-педагогической основе организовать воспитание детей в своей семье.

Многие исследователи занимались изучением детско-родительских отношений, дано множество классификаций детско-родительских отношений, выделены типы и виды детско-родительских отношений, изучены проблемы в семье и воспитании, но очень мало исследований в области того как отношения в семье влияют на развитие отношений ребенка со сверстниками.

Изучение детско-родительских отношений является важным как для понимания факторов и условий, влияющих на становление личности ребенка, так и для организации психолого-педагогической практики. О значимости данной проблемы свидетельствует тот факт, что многие психологические теории не обошли вниманием эту проблему (В.С. Мухина, В.Н. Мясищев, И.М. Балинский, А.В. Петровский и другие), рассматривая взаимоотношения родителей и ребенка как важный источник детского развития.

В учебном пособии «Психолого-педагогические аспекты взаимодействия детей со сверстниками» В.Н. Белкина рассматривает взаимодействие детей как «...сложный процесс непосредственных и опосредованных взаимных воздействий детей друг на друга, в результате которых происходят изменения в поведении, интеллекте и личности каждого ребенка».

Проблема межличностных отношений старших дошкольников на сегодняшний день является одной из актуальных. Это связано с тем, что межличностные отношения зарождаются и наиболее интенсивно развиваются в детском возрасте. С самого рождения ребенок живет среди людей и неизбежно вступает во взаимодействие с ними. Поэтому опыт первых отношений, как с взрослыми, так и со сверстниками является фундаментом для дальнейшего развития личности ребенка. Первое общение с людьми, также во многом определяет особенности самосознания человека, его отношение к миру, его поведение и самочувствие среди людей.

Вопросы, посвященные проблеме детско-родительских отношений, рассматривались учеными на протяжении всего развития психологической науки и практики. В отечественной психологии исследованиями в этой области занимались ученые Божович Л.И., Выготский Л.С., Дубровина Л.С., Лисина М.И., Леонтьев А.Н., Мухина В.С., и др.

Различные аспекты особенностей внутрисемейных отношений изучали М. Буянов, А.Я. Варга, Ю. Гиппенрейтер, А.Е. Личко, А.С. Спиваковская, Э.Г. Эйдемиллер, Г. Хоментаускас, А. Фромм и др. 
Решающая роль семьи в формировании личности ребенка, в воспитании его нравственно-духовных, эмоциональных, интеллектуальных качеств подчеркивается в трудах известных русских педагогов и общественных деятелей К.Д. Ушинского, Н.И. Пирогова, П.Ф. Каптерева, Д.И. Писарева, Н.В. Шелгунова, А.П. Нечаева, а также В.А. Сухомлинского.

Рассматривая различные подходы к понятию детско-родительские отношения, стили и типы семейного воспитания, причины возникновения дисгармоничного поведения мы делаем вывод, что главная роль принадлежит тем, кто принимает в жизни детей непосредственное участие и имеет с ними каждодневный контакт - родителям. Можно с уверенностью сказать, что на то, как сложиться жизнь ребенка в дальнейшем, на его поведение с окружающими существует прямая зависимость того как ребенок воспитывается в семье, будь то полная семья или один родитель. Под влиянием типа родительских отношений формируется личность ребенка.

В семье ребенок опосредует нормы человеческого общежития, усваивает нравственные ценности. Ее воспитательные воздействия определяют характер поведения ребенка вне семьи. Известно, что к концу дошкольного возраста складывается более или менее определенный тип отношения к сверстнику, который либо обеспечивает нормальное общение и сотрудничество, либо ведет к трудностям в общении с другими детьми, которые порождают тяжелые и острые переживания (обиды, неприязнь, зависть, злость и др.). Такие детские переживания могут стать в дальнейшем источником серьезных межличностных и внутриличностных проблем взрослого человека.

Естественно, возникает вопрос об источниках и факторах формирования того или иного типа отношения к другим детям. Среди них обычно выделяют опыт общения со сверстниками, в котором отрабатываются коммуникативные навыки и формируются дружеские отношения между детьми. Однако практика показывает, что опыт пребывания в детском коллективе сам по себе не обеспечивает доброжелательного отношения к сверстникам. Можно полагать, что главным фактором, определяющим характер отношения к сверстникам, является отношение к ребенку близких взрослых, в котором закладывается фундамент его самосознания.

Тема межличностных отношений детей различных дошкольных возрастов в группе детского сада отражена во многих психолого-педагогических исследованиях А.И. Аржановой, П.В. Артемовой, В.Я. Вороновой, В.А. Горбачевой, Р.Н. Ибрагимовой, Д.В. Менджерицкой, В.Г. Нечаевой, Р.И. Жуковской, Р.М. Римбург и др.

В исследованиях отечественных ученых М.И. Лисиной, а также ее сотрудников и учеников Л.Н. Галигузовой, А.Г. Рузской, О.Е. Смирновой, Р.Б. Серкиной и др., работающих в русле ее концепций рассматривается общение детей дошкольного возраста, с взрослыми и сверстниками.

Психологи относят потребность в общении к числу важнейших условий формирования личности. В связи с этим потребность в общении рассматривается как следствие взаимодействия личности и социокультурной 
среды, причем последняя служит одновременно и источником формирования данной потребности.

К шести годам возрастает количество просоциальных действий, эмоциональная вовлеченность в деятельность и переживания сверстника. Это объясняется развитием децентрации, благодаря которой ребенок становится способным понимать точку зрения другого (Ж. Пиаже).

Во многих исследованиях отмечается, что к старшему дошкольному возрасту складываются устойчивые способы отношений детей друг к другу. Так, Е.В. Субботский считает, что взаимоотношения дошкольников со сверстниками характеризуются, с одной стороны, импульсивностью и непосредственностью, а с другой стороны, инертностью и стереотипностью.

Теоретический анализ психолого-педагогической литературы показывает, что именно сверстник выступает в качестве равного партнера, в процессе общения, с которым ребенок может апробировать знания и социальные нормы, данные взрослым. Общаясь со сверстниками, старший дошкольник имеет возможность решать различные коммуникативные задачи, учится выстраивать отношения с окружающими по определенным правилам. Особое значение приобретает тот факт, что через межличностное общение со сверстником у ребенка может сформироваться адекватное представление о себе и своих возможностях, развивается самооценка, формируются определенные личностные качества.

Развитие межличностных отношений ребенка можно представить как сложное переплетение и взаимосменяемость этих двух начал в отношении к себе и к другому. Изменение соотношения предметного и личностного начала в отношении к себе и к другому задают возрастные и индивидуальные варианты личностного развития ребенка.

Убедившись, что семья прямым образом влияет на особенности становление межличностного взаимодействия детей со сверстниками, в дальнейшем нам необходимо выяснить какие именно условия будут успешно этому содействовать, мы проанализируем особенности воспитания в семье и изучим детский коллектив, какое место занимает ребенок в коллективе, его особенности общения со сверстниками. На основе этого попытаемся разработать систему мероприятий (тренинги для родителей, совместные игры, досуг), чтобы сделать детско-родительские отношения более успешными для становления межличностного взаимодействия старших дошкольников.

\section{Литература}

1. Леонтьев А.А. Общение как объект психологического исследования. // Методологические проблемы социальной психологии. - М., 1975.

2. Субботский Е. В. Стиль общения как способ формирования личности ребенка // Психолого-педагогические проблемы общения. — М.: Педагогика, 1979. $-187 \mathrm{c}$.

3. Выготский, Л.С. Педагогическая психология / Л.С. Выготский. - М.: ACT, 2005. - $670 \mathrm{c}$.

4. Лисина, М.И. Формирование личности ребенка в общении / М.И. Лисина. - СПб.: Питер, 2009. - 318 с. 
5. Рояк, А.А. Психологический конфликт и особенности индивидуального развития личности ребенка / А.А. Рояк. - М.: Педагогика, 1988. - 117 с.

\title{
ИНФОРМАЦИОННАЯ КУЛЬТУРА КАК УСЛОВИЕ СОЦИАЛИЗАЦИИ ЛИЧНОСТИ ПОДРОСТКА
}

\author{
Ермолова B.O. \\ Научный руководитель: к.псх.н., доцент Макаревская Ю.Э.
}

В XXI веке невозможно представить межличностные коммуникации подростков без использования возможностей информационной технологий. Это уже не просто достижение науки и техники, информационные технологии неотъемлемая часть жизни, которая обеспечивает бесперебойные коммуникации с внешним миром. IT-технологии воздействуют на все сферы жизни подростка, в том числе на его интеллектуальное, психоэмоциональное развитие и социализацию личности в целом.

За последние 10 лет с появлением IT-технологий в мире стала складываться информационная культура. Тенденции, которые она задает, имеют повсеместное распространение в обществе и практически не поддаются контролю. Скорость распространения информации стала почти мгновенной, география информационной культуры не имеет границ. Дистанционность, отсутствие контроля и анонимность сделали информационную культуру привлекательной, опасной и глобальной. К числу возможностей, которые открывает информационная культура, добавились опасности и угрозы, приносящие ущерб для духовного и физического здоровья человека.

В существующих условиях информационной культуры наиболее актуальной становится проблема включения каждого человека в единую социально-информационную систему и саму структуру общества. Ключевым элементом данного процесса является социализация личности, позволяющая человеку стать полноценным членом общества.[2] Но учитывая современные реалии, это становится невозможным и недоступным в полном объеме без информационной компетентности, которая представляет собой «способность человека в полной мере осмыслить и использовать возможности информационного общества, всесторонне адаптироваться и самореализоваться в нем» [3, с. 37-43].

Говоря об информационной компетентности, необходимо учитывать ее значимость в процессе социализации подростка: чем более человек информационно компетентен, тем он становится более востребованным в информационном обществе. Информационная компетентность приобретается человеком и совершенствуется как индивидуально, так в условиях социальных институтов при соответствующем образовании. Таким образом, именно информационная компетентность становится главным условием успешной социализации личности подростка в новой информационной среде общества.

Кроме того, информационная культура и в целом оказывает влияние на каждую из основных фаз процесса социализации личности подростка. Так на первой фазе, которая заключается в освоении социальных ценностей и норм 